\title{
Audiovisual Reception and MALL: Adapting Technology to Real Needs
}

\author{
NoA TalaváN \\ José JaVIER ÁvilA-CABreRA \\ Universidad Nacional de Educación a Distancia, UNED
}

Received: 4 June 2014 / Accepted: 9 November 2014

ISSN: 1697-7467

\begin{abstract}
Teaching listening comprehension has always been a difficult task given the subjectivity that this language skill entails. This may be one of the reasons why traditional foreign language learning methodologies have most often been aimed at its assessment than at its enhancement. Nowadays, we should speak in terms of audiovisual reception skills, given the great amount of audiovisual input we receive regularly and the significant changes brought about by new technological advances. This paper offers a methodological proposal aimed at improving audiovisual reception through the use of video and audiovisual language within well-structured tasks inserted in an innovative mobile application.
\end{abstract}

Keywords: Audiovisual reception, listening comprehension, audiovisual language, foreign language learning, Mobile Assisted Language Learning.

La recepción audiovisual y el aprendizaje móvil: Cubriendo necesidades con apoyo tecnológico

RESUMEN: La enseñanza de la comprensión oral siempre ha sido una ardua tarea dada la subjetividad intrínseca de esta destreza. Este puede ser uno de los motivos por el que las metodologías tradicionales de enseñanza de lenguas extranjeras se han centrado más en su evaluación que en su desarrollo. Hoy día, deberíamos hablar en términos de destrezas de recepción audiovisual, dada la cantidad de información recibida de este modo y los importantes cambios educativos surgidos de los últimos avances tecnológicos. El presente artículo ofrece una propuesta metodológica basada en la mejora de la recepción audiovisual a través del uso del video y del lenguaje audiovisual partiendo de una serie de tareas estructuradas incluidas en una innovadora aplicación móvil.

Palabras clave: Recepción audiovisual, comprensión oral, lenguaje audiovisual, enseñanza de lenguas extranjeras, Aprendizaje de Lenguas a través de Dispositivos Móviles.

\section{INTRODUCTION}

It is often said that one of the most complex communicative activities (to define, teach and learn) is listening comprehension. This is a fact, given the wide variety of processes that take part in the individual when this skill is used: neurological, linguistic, psycholinguistic and pragmatic. This may be one of the reasons why it is a skill that has somehow been left behind as far as research is concerned within the field of foreign language (L2) learning. This oversight is even more acute when it comes to its use within Computer Assisted Language 
Learning (CALL), given the added difficulty involved in controlling all these subjective elements in an online environment.

Solutions to this shortage of research, methodology and materials should be urgently sought, especially if we take into account the speed of development of the technological world; nowadays, the use of computers is somehow being overridden by smartphones and tablets, and language students increasingly expect to be able to practice communicative skills audiovisually and on the move, whenever and wherever they might be. In this new context, first of all, we should be speaking of audiovisual reception (AVR), and not about mere listening comprehension anymore, since the former is at present much more common in everyday communication. The power of audiovisual language is a very relevant field to be explored within this context, given the potential benefits its pedagogical use can bring about. Finally, if we want to adapt the enhancement of AVR to real needs, we should focus on Mobile Assisted Language Learning (MALL), and start searching for new methodologies to teach and learn this complex communicative activity through mobile applications.

This article will first present the nature of listening comprehension, to later focus on AVR and the pedagogical potential of audiovisual language. Then, the existing research on the use of MALL to enhance listening comprehension will be reviewed to finish up with the presentation of an innovative proposal involving the use a mobile application for the development and assessment of AVR: the VIOLIN app.

\section{The Nature of Listening Comprehension}

Listening comprehension is a multisensory process that typically involves attending to and encoding not only the auditory properties of the message conveyed, but also the visual attributes of the speakers and this multisensory integration of speech occurs naturally and automatically in listeners of all ages. Given that nowadays we spend a great amount of time in front of a screen, we have come to be accustomed to both listening to and watching all types of messages. That is why teaching listening comprehension nowadays should be more focused on the most natural and realistic mode in which listeners usually face this skill, i.e. audiovisually. AVR is in fact mentioned as such, identified as one of the main communicative activities to be practiced and learned in the foreign language learning context, according to the Common European Framework of Reference for Languages (CEFR) (Council of Europe, 2001:71) with the corresponding description in terms of levels and can-do statements: "Can identify the main points of TV news items reporting events, accidents, etc. where the visual supports the commentary" (example from A2).

Even if listening comprehension had been left somewhat behind as far as research is concerned, it should be noted that this situation has considerably improved in the past decades thanks to the work of a series of authors (Brown, 1995; Buck, 2001; Rost, 2002, among others) who have claimed the relevance of this skill, analysed its components thoroughly and suggested diverse strategies for its proper acquisition and assessment.

Defining listening comprehension or AVR is not an easy task. It is an intangible and a very subjective mental process where a particular person builds the global meaning of an 
audiovisual text, so that it is influenced by multiple factors relative to the person building the message and the time when it is produced. Rost (2002) describes four categories around which listening comprehension can be defined: receptive (the reception of individual words by the hearer), constructive (the construction and representation of the message), negotiative (the negotiation of the meaning with the speaker and the answer received) and transformative (the creation of meaning through participation, imagination and empathy). The most relevant in the context of AVR would be the constructive category; besides, it includes the receptive one to a certain extent, and the other two (negotiative and transformative) cannot exist without it (Talaván, 2010).

Focusing on the constructive nature of listening comprehension, the main three elements that make up this constructive process can be said to be: (1) the interlocutors, (2) the text received and (3) the situation. The speaker and the listener are the main interlocutors in a conversation, being involved in a bi-directional active process; moreover, in situations where there is no negotiation involved (for example AVR, in front of a screen), the listener is nowadays becoming increasingly active thanks to the ever-growing interactive nature of Information and Communication Technologies (ICTs) in general. As far as the speaker is concerned, there is a series of related variables that may facilitate or complicate the listener's reception: speed of speech, the variety of the pronunciation, voice familiarity, the number of speakers, the speakers distinction, and gender. Additionally, there is a series of aspects that influence comprehension as regards the listener that need to be borne in mind (Cornaire, 1998): linguistic competence, short-term memory, possible lack of attention, emotion, age, and knowledge.

The oral text differs widely from the written text, not only in physical terms (speed of speech, background noises), but also linguistically (ellipsis, backchanneling, overlapping) and psychologically (potential interaction and negotiation with the speaker). However, the major difference between written and oral texts may be said to be the fact that people generally speak with short expressions or "idea units" (Buck, 2001:9). These idea units are connected by coherence factors instead of grammatical rules. Also, when dealing with oral discourse, it is essential to distinguish planned and spontaneous exchanges. As a general rule, planned texts have been the most common type of texts used in the language learning context and the problem of this tendency is the potential difficulty that students may encounter when they face real spontaneous texts. That is why the use of authentic texts in the form of video clips taken from films or TV shows should be encouraged as the closest possible examples of spontaneous discourse to enhance AVR.

The final factor that influences the constructive process is the situation, as far as the cultural context, the pragmatic context, the cognitive context, and the situational context. The situation is much more comprehensive and clearer in audiovisual texts because most of the elements needed to understand the situation properly are present; in oral texts, however, we should speak of an information gap in this regard, something that can make the reception process harder for the student.

No matter how complex the nature of this skill might be, it should not be forgotten that listening comprehension (including AVR) is one of the pillars of real life communication, as well as one of the L2 skills students usually find more difficult to develop. That is why current trends involving the use of ICTs in this context, such as MALL, should aim at looking for innovative designs and methodological approaches that can help learners in this regard. 


\section{Audiovisual language}

When we use video in the language class, students practice their AVR skills and face audiovisual language. Using video in this context means, nowadays, watching video clips within a technological framework, be it through a DVD player, a projector, a computer, a smartphone or a tablet.

The use of video for language learning purposes has been largely discussed throughout several decades now (Talaván, 2007), but unfortunately its didactic applications have not received the attention it deserves. Most practitioners lacked the appropriate training in this regard and often utilize video without guidance and not following any particular methodological approach. Hence, both teachers and students have often failed to appreciate its real pedagogical value and researchers have not felt inclined to devote too much effort to the field.

The use of video in class entails the combination of verbal and non-verbal elements that makes learning more realistic and thorough. In addition, when authentic videos are employed, the students are offered the chance to access to cultural awareness and experience language beyond its use in the classroom, something essential within their learning process (Nunan, 1999).

When video is properly used, through short sequences, from 30 seconds to three minutes approximately (to avoid attention drop, as Cornaire (1998) puts it) and acting as the center of a complete and well-built task, its didactic benefits are enhanced. It is also of fundamental importance to select the clip appropriately (according to the students' linguistic level, the language content and other relevant criteria such as interest, humor, number of characters, etc.), and to build the task in advance, with pre-viewing, viewing and post-viewing activities so as to make the most of the selected video (Talaván, 2013).

It should be noted that the language contained in most videos used in class is neither planned nor spontaneous, but a particular kind of language called audiovisual language. According to Pavesi (2012), audiovisual language can play a paramount role as regards the improvement of the different linguistic skills, namely written and oral production, written and oral comprehension, and vocabulary acquisition, as well as cultural awareness.

As the power of audiovisual language lies in its perfect combination of spontaneous conversation and screen dialogue, which softens the inherent difficulty of spontaneous communication (given by the great amount of hesitations, false starts, hedges, etc.), students can become familiar with these elements while they do not constitute a hindrance to comprehension.

It is of note that the use of video to enhance AVR often means missing bidirectional interaction, and this can be considered an undeniable constraint given the non-interactive nature of the input. However, when we communicate in our mother tongue (L1), there are also many situations that do not include interaction but contain AVR (e.g. watching a movie, a play at the theatre, Internet videos or TV). Furthermore, these unidirectional situations are easier than those that include meaning negotiation and so are a perfect start point for learners so as to manage to feel more confident when facing real interactions.

Among the main benefits of audiovisual language with regard to L2 acquisition, Pavesi (2012) stresses the following issues: (1) it presents a great amount of linguistic features that are common to face-to-screen communication; (2) as it contains spontaneous utterances 
similar to real language, its use can foster the learner's acquisition of common conversation structures; (3) and other aspects, such as "greater fluency and reduced vagueness, greater discourse immediacy, formulaicity and predictability" (Pavesi, 2012:10). ${ }^{1}$

There are a few studies on the naturalness of the language spoken in movies and TV shows in relation to face-to-face conversation corpora, but the existing ones account for the innumerable similarities this type of language shares with real spontaneous conversation. Quaglio (2009), for example, compares the language of the popular American sitcom Friends (Crane and Kauffman, 1994-2004), with the Longman Grammar Corpus and finds the AVR very similar to the linguistic features of spoken registers. Forchini (2009) focuses on the cinematographic language of 11 American movies contrasted with the Longman Spoken American Corpus and she unravels that both conversational varieties do not differ extensively (after a thorough quantitative and qualitative analysis). Lastly, Rodríguez Martín and Moreno Jaén (2009) made use of a micro-corpus composed of 10 American movies and compared their conversational components with others included in the British National Corpus to find that Anglophone movies exhibit spontaneous exchanges closer to spoken English than to written language. Most of these authors acknowledged the ample potential of AVR for pedagogical purposes in L2 education.

Hence, the didactic potential that audiovisual language can offer learners can be said to be even more pedagogically appropriate than the one spontaneous conversation could provide; these intrinsic benefits related to authenticity are enhanced by the familiar leisurerelated motivational factor implied when students watch this type of audiovisual products.

\section{Teaching AVR}

Up to now, most researchers and practitioners have discussed listening comprehension in general, no matter the nature of the input. Since this article attempts to bring this skill closer to reality and modern times, this section will provide general guidelines to adapt the teaching-learning process to real AVR needs.

It should be noted that AVR can be taught face to face or in distance education contexts (using CALL or MALL resources). It can be enhanced on its own or within an integrated skills scenario; it is recommended to practice both stances, the former to help students to focus on the skill and its functioning so as to understand it better and the latter in order to be able to integrate its use within real and comprehensive communicative contexts.

The main elements involved in the teaching-learning process are obviously the teacher, the student and the tasks. Although teachers are not supposed to play a very active role nowadays, they need to prepare/select the tasks appropriately so that they may later just focus

\footnotetext{
${ }^{1}$ Audiovisual language offers better fluency given its previous preparation through a script, a fact that also accounts for a less vague language, where the only existing vagueness is rehearsed, i.e. not real, taking away two inconvenient features (vagueness and lack of fluency) that real spontaneous conversation presents. Finally, it is a more predictable language since it contains a larger number of linguistic formulae. These four final features can be said to make audiovisual language extremely suitable for the pedagogical context.
} 
on monitoring the students' active role while working on the activities. In fact, the students are the total protagonists of the teaching-learning process and, in terms of listening comprehension in general (including AVR) they are said to undergo three stages (Vandergrift, 2011): perceiving, processing and producing. Traditionally, listening comprehension activities only paid attention to the first phase, but fortunately, the three stages are currently increasingly included; the problem as regards AVR is that interaction is commonly out of the picture, so the final stage, language use, needs to be included as a delayed task, in the form of the students' related language productions (oral or written) sent for correction.

Focusing the attention on the student, the main elements to work on when AVR is to be enhanced are the corresponding learning strategies that can help learners to develop this skill as efficiently as possible. Although there are not many studies conducted on listening strategies, some authors have focused on training students on strategy use to improve their skills when dealing with listening tasks through think-aloud methods (Murphy, 1985; Chamot and Kupper, 1989; O’Malley et al., 1989), questionnaires (Fujita, 1985; Vandergrift, 2005), interviews (Vandergrift, 1997; Goh, 2002), recall tasks (Moreira, 1996; Schmidt-Rinehart, 1992), listening strategies inventories (Fujita, 1985), just to cite some of them. Murphy (1985) carried out the first study on listening strategies between skilled and less skilled learners, where he explored 17 individual strategies placed into a taxonomy of six categories: recalling, speculating, probing, introspecting, delaying and recording. The results proved skilled learners to make use of a larger variety of strategies, whereas less skilled students paid too much attention to the text and their knowledge. On the other hand, Henner Stanchina (1987) accounted for the roles played by metacognitive strategies regarding listening comprehension and discussed that proficient listeners are able to address failure in comprehension and resort to knowledge to retrieve the missing understanding. Other authors have investigated the use of different types of listening strategies with high school students (Rubin, 1988; Chamot and Kupper, 1989; O'Malley et al., 1989; Vandergrift, 1997) and with university students (Bacon, 1992a, 1992b). All the studies so far have, nonetheless, relied on qualitative research and their results cannot be said to be conclusive. Abdalhamid (2012) looks into Arabic-speaking learners' listening strategies in an attempt to cover the lack of quantitative research in this field. Not only has he proven that advanced and intermediate learners employ cognitive, metacognitive and socioaffective strategies, but suggested that beginners should be instructed to make use of listening strategies with the aim of improving their listening comprehension skills. The use of strategies therefore plays a paramount role in the improvement of students' listening comprehension skills, as well as in the development of AVR.

The last elements to be discussed within the teaching-learning process are the tasks. According to Rost (2002), it is necessary to distinguish different types of listening and lead the students to practice all of them through the tasks, so that they can develop all the necessary skills involved in this communicative activity: intensive listening (distinguishing sounds, words, phrases and sentences through dictation, cloze tests and/or related activities), selective listening (focusing the attention on specific information or idea units, through note-taking, for example), and interactive listening (as part of a conversation where interaction and negotiation are involved). There are other types of listening mentioned by other authors, such as attentive listening or even global listening, that should also be borne in 
mind depending on the type of task at hand. Dealing with AVR, the types of listening that play a role are those that do not involve interaction of any kind; this is not negative, since plenty of AVR performed in our (L1) is also non-interactive. Once this is clear, tasks should follow a particular pre-designed structure, and the basic elements that are normally considered appropriate to make up such a thorough activity are (Talaván, 2010): a pre-listening phase, where expectations are created (around 15\% of the task); a listening phase, where the student's attention is focused on the whole process (50\% of the task approximately); finally, a post-listening stage, where the learner checks what has been understood and so assesses the correct progress of the previous phases and proceeds to language use (35\% of the task time).

It is impossible to close this section without commenting on the various modes of assessing AVR. Teaching and assessing listening comprehension should be clearly distinguished, since for many years, this communicative activity has been unfortunately taught by assessing it; that is to say, it was not really taught, but just assessed in class. Cohen (1980:1) refers to a series of wh-questions in terms of L2 assessment that can be easily applied here: "why, when, what, what for and how to assess". Once these questions have been answered, teachers and material developers have to decide on the assessment approach and the type of tests to be employed (Buck, 2001).

Teaching listening comprehension only based on oral texts does not seem to be very practical in the present multimodal world, and so teachers, researchers and students could start talking about this skill in terms of AVR more often in the L2 context. As it is rare for people to just listen (without watching) nowadays, so the typical audio tracks traditionally included in most textbooks should be increasingly substituted by audiovisual texts. AVR is then to be taught, acquired and assessed in the educational context the way listening comprehension has been up to now, with the slight modifications the change in the type of input will obviously bring about.

\section{Audiovisual Reception and Mobile Assisted Language LEARNING}

When the audiovisual medium is used, the L2 educational environment can become an active and multisensory context where didactic resources can be used in a participatory and productive manner. Nowadays, this multimodal educational context is often framed within CALL and MALL. With the fast and extensive growth of technology, an ever increasing number of pedagogical tools play a significant role as far as L2 learning is concerned, given their easy access, great variety and flexibility of use. In this setting, looking into new methodologies to enhance such an important skill as AVR through mobile applications becomes a must.

The sound and visual intensity offered by CALL and MALL, and its multidimensional and multisensory representations are the perfect setting for the enhancement of AVR. With the combination of the Internet, ICTs and multimedia products, texts have become more visual, multimodal and interactive. In this context, the students may enhance their reception skills, for example, by watching videos or even sharing and making their own audiovisual products. 
The gap between technology and pedagogy can and should be bridged by means of teachers' contributions in CALL and MALL research, in the form of research-based materials (Colpaert, 2006). In this regard, the following two studies are examples of recent attempts to research the integration of ICTs and listening comprehension/AVR skills. Pardo-Ballester's (2012) experiment deals with the students' attitudes towards the use of CALL with authentic clips to support the enhancing of listening skills. Her study proved how beneficial the use of clips were for fostering listening and speaking skills. Zou (2013) discusses how teachers can support students to make use of CALL activities efficiently to enhance listening and speaking skills. The use of questionnaires, interviews and observations from teachers' and students' views provide some insights into fruitful manners for teachers to help students use computers more effectively in the L2 practice.

If we focus exclusively on the ever-growing field of MALL, though difficult to define and categorize because of the fast growth of technological tools, it is clearly becoming a new educational framework, which offers users a wide range of possibilities (Traxler, 2005). MALL has been related with handheld computers and mobile phones, and research on related technologies and L2 methodologies can be said to be rather immature. However, the growth of international conferences and workshops (e.g. mLEARN 2002-2014) has made MALL increasingly more visible and thus the theory and practice of learning and mobility in converging technological environments is being more thoroughly covered.

As far as MALL research is concerned, Viberg and Grönlund (2012) deal with the literary review of the last few decades. The characteristics of MALL have been pointed out by Ogata and Yano (2005) in terms of permanency, immediacy, interactivity and situating of instructional activities. The advantages of MALL, in terms of flexibility, low cost, small size, user-friendliness, have been highlighted by Huang et al. (2012), and its disadvantages by Albers and Kim (2002). Although there is still lack of specific research on MALL and AVR, more studies are being and will be carried out within this field (Calle et al., 2014; Castrillo de Larreta-Azelain, 2014), as innovations are currently gaining more weight in the field.

\section{Proposal of a Mall Application to Develop and Assess AVR}

Most MALL applications help students with basic concepts and skills, but it is uncommon to find a well-defined methodological basis in the presentation and structure of activities (Chinnery, 2006). The most common skills included in the existing mobile applications are related to language content (grammar, vocabulary, etc.) and it is not that frequent to encounter apps devoted just to listening comprehension or AVR (the latter even less common). The proposal presented below attempts to help us cover this gap by designing a mobile app with which the students will be able to foster AVR making use of entertaining videos, extracted from the famous TV show Friends, which are designed to be introduced, played and related with comprehension questions at various stages. The name of this app is VIOLIN (VIdeOs for LIsteNing), and although it is not fully implemented yet (in technological terms), a demo version containing six videos/activities will be soon available and piloted at the UNED (Universidad Nacional de Educación a Distancia). Figure 1 shows the app's main screen. 


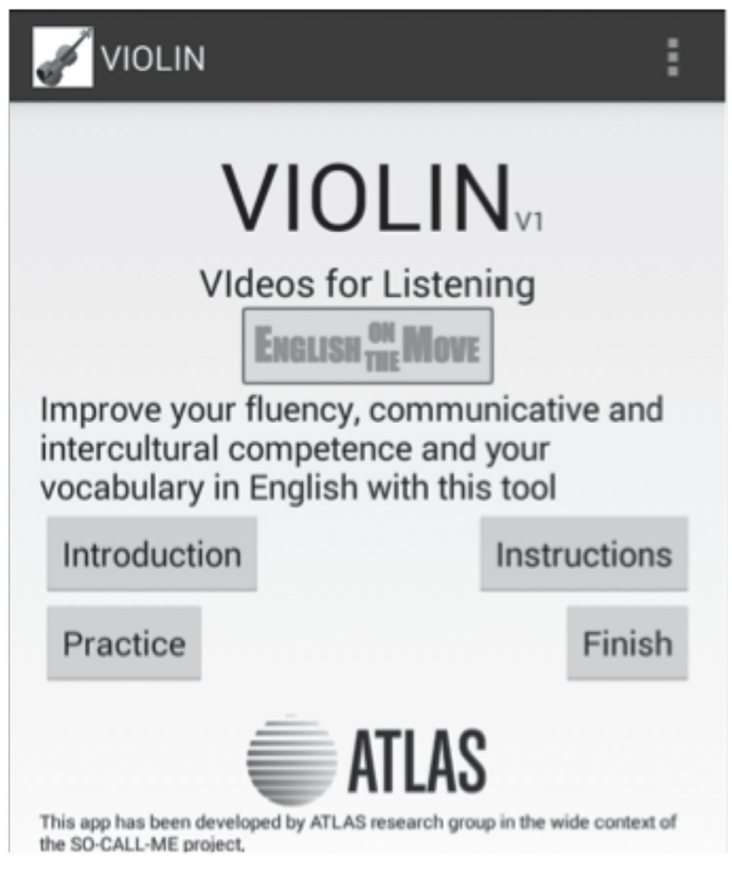

Figure 1. VIOLIN welcome screen

The app includes six short videos as the basic resources around which six activities are developed. All selected clips (1-2 minutes) are chosen in terms of a particular communicative function that is present therein: "announcements", "presentations", "convincing", "encouraging", "announcements II" and "suggestions". The clip selection is based primarily on the following criteria: they are interesting, self-contained and context-independent, include only a few characters, the language content and the speed of speech rate are suitable for the corresponding level (B1, in this case), and they contain humorous elements.

The methodological design used to create VIOLIN takes into account the different stages involved in aural reception/listening comprehension, according to the CEFR (Council of Europe, 2001:71-72): planning (or framing, selecting mental set, activating schemata and setting up expectations), execution (identifying cues and inferring from them), evaluation (hypothesis testing, matching cues to schemata) and repair (revising hypotheses). Hence, every AVR activity in the app presents the following sequence: planning, through warm-up activities and viewing instructions; execution, where students are asked to watch the video and complete the accompanying activities; evaluation, getting feedback to their answers (right or wrong) and using a final short self-evaluation rubric; and repair, with advice notes suggesting revision whenever needed.

All activities are aimed at B1 level students of English and each should take between 8-10 minutes approximately to be completed. After encountering a general introduction to the app, the students can choose which activity to work on. 
Every activity is divided into the five stages, according to the general sequence detailed above, but in a very concise manner, bearing in mind that this is aimed at people learning through MALL, which may be working with the app on the move (e.g. while waiting for the train).

- Firstly, the student encounters an introduction stage, presenting the activity and suggesting warm-up work through open questions. An example of this stage from activity six ("Suggestions") is presented below:

You are going to watch a clip where Joey and Chandler are trying to find a good stage name for Joey, so they are discussing different options.

Try to make some suggestions in English... Click here to see a few examples: How about going to the cinema? / ... and ...to the theatre? /...you might want to try this / Let's do this... / What about...?

- Then, the first viewing that looks at the development of selective listening, i.e. at teaching students how to predict information and select the appropriate cues that surround this information. In our case, this is achieved through AVR guidelines and accompanying questions, as explained in activity 3 ("Convincing"):

Time to watch the clip (selective listening): now watch the video focusing on the way Rachel starts to be absent thanks to her imaginary conversation with Ross. You will find related questions after watching the video.

- The following stage involves a second viewing, where intensive listening is put into practice. This type of AVR practice focuses on language form. The main aim is to help students to realize how differences in terms of structure, lexical choice or sound can influence meaning and comprehension. In our case, this is achieved through comprehension guidelines and specific questions involving 'mental' notetaking. Here is an example taken from activity 4 ("Encouraging"):

Time to watch the video again (intensive listening): now watch the clip once again and pay attention to all the short encouraging expressions you hear (examples: yeah / go over / come on...). It is useful if you can note them down. You will be able to check them afterwards.

- The third and final viewing looks at global listening, in terms of helping students to understand the general message or messages exchanged in interpretative terms. To this end, and given that the clips are humorous, the common AVR guidelines are followed by questions in this section devoted to understanding the main gags or funny situations, as shown in activity 2 ("Presentations"):

Now let's watch the clip a final time (global listening): it's time to watch the video a third time, trying to understand all the messages. It would be a good practice to try to understand the gist of the funniest situation/spot of the clip. There will be related questions after the clip. 
- Finally, all the activities contain the same self-evaluation rubric and final help note to promote post-viewing activities, as well as to encourage 'repair' or revision if necessary at a later stage.

Now take a couple of minutes to think about the strategies you have used to understand the video:

- Problem-solving (making and monitoring inferences using your previous knowledge) (yes/no)

- Mental translation (using your mother tongue) (yes/no)

- Planning-evaluation (previous preparation and evaluation of the results of your efforts) (yes/no)

- Person knowledge (assessing the perceived difficulty) (yes/no)

- Directed attention (maintaining attention and controlling train of thought) (yes/ no)

Final help note: Try to practice some of the expressions you just learned in future conversation practices in English (with a classmate or on your own). If you had problems understanding the video, we suggest that you repeat the activity (after a few hours or a day have passed) to check your improvements in comprehension.

Attentive and interactive listening are not included here given the non-bidirectional nature of the L2 learning context within MALL. Nonetheless, research will be conducted in an attempt to prove whether the use of the present app proves to be beneficial in terms of listening comprehension and AVR within the context of L2 learning on the move and how it could be improved, enhanced or complemented.

\section{Conclusion}

This paper has explored the ways L2 learners can improve AVR, based on theoretical assumptions regarding the nature of listening comprehension and more recent approaches that take into account the nature of audiovisual language and the possibilities offered by MALL.

The vast number of resources available nowadays can help teachers and researchers look for new forms of AVR enhancement, combining leisure with learning, and far from the traditional approaches that basically focused on the passive and isolated assessment of listening comprehension. It is in this context where the potentials of audiovisual language, as a very familiar element, could be incorporated into mobile applications which can be used on a variety of electronic devices, that is currently increasingly extended to a myriad of users.

We do hope that the innovative VIOLIN app presented here (although not fully developed and hence not available yet), which combines the traditional viewing of videos with controlled activities to be followed at different stages, may serve as a valid methodological proposal for both researchers and practitioners in search of thorough, entertaining and authentic listening-oriented activities, which serve not only as recreation tasks but which can open the door to related proposals aimed at the improvement of L2 learners' AVR skills, thus somehow adapting technologies to real needs. 


\section{Acknowledgements}

We would like to thank the Spanish Ministry of Science and Innovation for funding the SO-CALL-ME research project (Research grant number: FFI2011_29829).

\section{REFERENCES}

Abdalhamid, F. (2012). Listening Comprehension Strategies of Arabic-Speaking ESL Learners. (Doctoral dissertation, Colorado State University).

Albers, M. and Kim, L. (2002). "Information design for the small-screen interface: An overview of Web design issues for personal digital assistants”, in Technical Communication, 49, 1: $45-60$.

Bacon, S.M. (1992a). "The relationship between gender, comprehension, processing strategies, and cognitive and affective response in foreign language learning", in Modern language Journal, 76: 160-178.

Bacon, S.M. (1992b). "Phases of listening to authentic input in Spanish: A descriptive study", in Foreign Language Annals, 25, 4: 317-334.

Brown, G. (1995). Speakers, Listeners and Communication. New York: Cambridge University Press.

Buck, G. (2001). Assessing Listening. Cambridge: Cambridge University Press.

Calle, C., Rodríguez-Arancón, P. and Arús-Hita, J. (2014). "A scrutiny of the educational value of EFL mobile learning applications", in Cypriot Journal of Educational Sciences, in press.

Castrillo de Larreta-Azelain, M.D. (2014). "Learners attitudes toward collaborative writing in elanguage learning classes: A twitter project for German as a foreign language", in Revista Española de Lingüistica Aplicada (RESLA) 26: 127-138, available from http://dialnet. unirioja.es/servlet/articulo?codigo=4597559, accessed 20 January, 2014.

Chamot, A.U. and Kupper, L. (1989). "Learning strategies in foreign language instruction", in Foreign Language Annals, 22: 13-24.

Chinnery, G.M. (2006). "Emerging technologies. Going to the mall: Mobile assisted language learning", in Language and Learning \& Technology 10, 1: 9-16, available from http://ltt. msu.edu/vol10num1/emerging/default.html, accessed 15 December, 2014.

Cohen, A.D. (1980). Testing Language Ability in the Classroom. Rowley, MA: Newbury House Publishers.

Colpaert, J. (2006). "Pedagogy-driven design for online language teaching and learning", in CALICO journal 23, 3: 477-497, available from https://www.calico.org/a-102-Pedagogydriven+ Design + for + Online+Language+Teaching+and+Learning.html, accessed 5 November, 2013.

Council of Europe. (2001). Common European Framework of Reference for Languages: Learning, Teaching, Assessment. Cambridge: Cambridge University Press.

Forchini, P. (2009). "Spontaneity reloaded: American face-to-face and movie conversation compared", in Abstracts of the 5th Corpus Linguistics Conference. Liverpool, 118.

Fujita, J.N. (1985). A Preliminary Inquiry into the Successful and Unsuccessful Listening Strategies of Beginning College Japanese Students. (Doctoral dissertation, The Ohio State University, 1984). Dissertation Abstracts International, 45: 2424A.

Goh, C. (2002). Teaching Listening in the Language Classroom. Singapore: SEAMEO Regional Language Centre. 
Henner Stanchina, C. (1987). "Autonomy as metacognitive awareness: Suggestions for training selfmonitoring of listening comprehension", in Mélanges Pédagogiques 69-84, available from http://www.atilf.fr/IMG/pdf/melanges/6hennerstanchina.pdf, accessed 10 December, 2013.

Huang, Y.-M., Huang, Y.-M., Huang, S.-H. and Lin, Y.-T. (2012). "A ubiquitous English vocabulary learning system: Evidence of active/passive attitudes vs. usefulness/ease-of-use", in Computers and Education, 58: 273-282.

Moreira, M.L. (1996). On Listening Comprehension: Linguistic Strategies Used by Second Language Learners in Non-Collaborative Course. (Doctoral dissertation. University of Illinois, Urbana-Champaign, 1995). Dissertation Abstracts International, 56: 3562A.

Murphy, J.M. (1985). "An investigation into the listening strategies of ESL college students", in ERIC Document Reproduction Service, ED27875, available from http://files.eric.ed.gov/ fulltext/ED278275.pdf, accessed 10 October, 2013.

Nunan, D. (1999). Second Language Teaching and Learning. Florencia, Kentuky: Heinle \& Heinle Publishers.

Ogata, H. and Yano, Y. (2005). "Knowledge awareness for computer-assisted language learning using handhelds", in International Journal of Learning Technology, 5, 1: 435-449.

O’Malley, J.M., Chamot, A.U. and Kupper, L. (1989). "Listening comprehension strategies in second language acquisition", in Applied Linguistics, 29: 331-341.

Quaglio, P. (2009). Television Dialogue: The Sitcom Friends vs. Natural Conversation. Amsterdam: John Benjamins.

Pardo-Ballester, C. (2012). "CALL evaluation: students' perception and use of LoMasTv", in CALICO Journal 29, 3: 532-547, available from http://journals.sfu.ca/CALICO/index.php/ calico/article/view/22/42, accessed 20 December, 2013.

Pavesi, M. (2012). "The potentials of audiovisual dialogue for second language acquisition", in P. Alderete-Díez, L. Incalcaterra McLoughlin, L. Ní Dhonnchadha and D. Ní Uigín (eds.), Translation, Technology and Autonomy in Language Teaching and Learning. Oxford: Peter Lang, 155-174.

Rodríguez Martín, M.E. and Moreno Jaén, M. (2009). “Teaching conversation through films: A comparison of conversational features and collocations in the BNC and a micro-corpus of movies", in The International Journal of Learning, 16, 7: 445-58.

Rost, M. (2002). Teaching and Researching Listening. London: Longman.

Rubin, J. (1988). Improving Foreign Language Listening Comprehension. Washington DC: US Department of Education.

Schmidt-Rinehart, B.C. (1992). The Effects of Topic Familiarity on Second Language Listening Comprehension of University Students of Spanish. (Doctoral dissertation, Ohio State University).

Talaván, N. (2007). "Learning vocabulary through authentic video and subtitles". TESOL-SPAIN Newsletter, 31: 5-8.

Talaván, N. (2010). "Claves para comprender la destreza de la comprensión oral en lengua extranjera", in EPOS 26: 198-216, available from http:/dialnet.unirioja.es/servlet/ articulo? codigo $=3858352$, accessed 16 March, 2013.

Talaván, N. (2013). La subtitulación en el aprendizaje de lenguas extranjeras. Barcelona: Octaedro.

Traxler, J. (2005). "Defining mobile learning", in Proceedings of the IADIS International Conference Mobile Learning. Malta, 261-266.

Vandergrift, L. (1997). "The comprehensive strategies of second language (French) listeners: A descriptive study", in Foreign Language Annals, 30: 387-409.

Vandergrift, L. (2005). "Relationships among motivation orientations, metacognitive awareness and proficiency in L2 listening", in Applied Linguistics, 26: 70-89. 
Vandergrift, L. (2011). "L2 listening: Presage, process, product and pedagogy", in E. Hinkel (ed.), Handbook of Research in Second Language Teaching and Learning, Volume II. New York: Routledge, 455-471.

Viberg, O. and Grönlund, Å. (2012). "Mobile assisted language learning: A literature review", in mLearn 9-16, available from http://ceur-ws.org/Vol-955/papers/paper_8.pdf, accessed 27 November, 2013.

Zou, B. (2013). "Teachers' support in using computers for developing students' listening and speaking skills in pre-sessional English courses", in Computer Assisted Language Learning, 26, 1: 83-99.

\section{TV SHOW}

Friends. (1994-2004). Crane, D. and Kauffman, M. Warner Bros. Television and Bright/Kauffman/ Crane Productions. USA. 